\title{
The IMF and Protection of Vulnerable Groups
}

\author{
Viljam Engström \\ Adjunct Professor of International Law, Åbo Akademi University, \\ Turku/Åbo, Finland \\ vengstro@abo.fi
}

\begin{abstract}
The concept of vulnerability serves to focus protection on those most in need. While prominent in human rights law, protection of vulnerable groups is also increasingly invoked by international economic/financial actors such as the International Monetary Fund (IMF). The present article explores how vulnerability enters IMF policymaking. The article looks for points of contact of IMF practice, with a human rights-based conception of vulnerability. The aim of the article is not to revisit the discussion on human rights accountability of the IMF. Instead, the article seeks to identify and analyse the function of vulnerability in the policy-making of the Fund. The protection of vulnerable groups, the article claims, is gradually constituted as part of the law of the IMF. For this reason alone, it is of importance to know how vulnerability enters IMF policy-making and whom the IMF considers vulnerable. Moreover, the IMF also becomes a source for the identification of vulnerable groups.
\end{abstract}

\section{Keywords}

International Monetary Fund (IMF) - human rights - social protection - vulnerability

\section{Introduction}

Social protection has become a central concern in global policy discourse. The concept has arisen with "meteoric speed" on the international development 
agenda, ${ }^{1}$ in various international institutions, ${ }^{2}$ as well as in international human rights law. ${ }^{3}$ With social protection manifested as both an economic question as well as a question of human rights, approaches to social protection vary across international regimes. Consequently, social protection lacks a unitary definition. ${ }^{4}$ On the other hand, the openness of the concept is welcomed for its potential to bridge the discourse between human rights and economic realities, "bringing with it the prospect that a far more broad-based coalition of actors can be mobilised to promote implementation". ${ }^{5}$

Social protection is also likely to stay topical for decades to come. Maintaining a financially sustainable and equitable social protection system will continue to remain a challenge in developing countries. ${ }^{6}$ Environmental concerns will leave no country unaffected and the inevitable shift towards a low-carbon economy is predicted to pose significant risks to macroeconomic performance. ${ }^{7}$ Most advanced economies are also facing an impending demographic challenge. Adding to this developments such as displacement of workers, there seems to be no shortage of pressures on the financing of social welfare. This pressure is bound to raise questions concerning the distribution of that welfare, and with that, the level of social protection. ${ }^{8}$

1 This expression derives from A. de Haan, 'The rise of social protection in development: progress, pitfalls and politics', 26:3 European Journal of Development Research (2014) pp. 311-321, p. 311. The article is an outcome of the Academy of Finland funded research project RELAY, Vulnerability as Particularity - Towards Relativizing the Universality of Human Rights? [grant number 311297], at Åbo Akademi University Institute for Human Rights. Research on the article has benefited greatly from a research visit to the IMF and World Bank during the 2018 Spring Meetings. Special thanks are due to a number of people both at the IMF and the World Bank who found the time to discuss social protection issues. I am also grateful to comments from audiences at the Law and Development conference in Leiden in September 2018, at the Åbo Akademi University Institute for Human Rights research seminars, and Maija Mustaniemi-Laakso in particular, as well as to the reviewers of this journal.

2 See overview in Annex I to Independent Evaluation Office, The IMF and Social Protection (5 July 2017) p. 37.

3 As far as international human rights law is concerned, the right to social security is explicitly articulated in Article 22 of the Universal Declaration on Human Rights, and in Article 9 of the International Convention on Economic, Social and Cultural Rights, and is elaborated by the Committee on Economic, Social and Cultural Rights, in General Comment No. 19: The right to social security (Art. 9 of the Covenant), E/C.12/GC/19 (4 February 2008).

4 The World Bank, The World Bank 2012-2022 Social Protection and Labor Strategy (2012).

5 Report of the Special Rapporteur on extreme poverty and human rights, Extreme poverty and human rights, UN Doc. A/69/297 (11 August 2014), para. 3.

6 See http://socialprotection-humanrights.org/key-issues/financing/, visited 28 August 2018.

7 The Managing Director's Statement on the Role of the Fund in Addressing Climate Change, 25 November 2015, International Monetary Fund.

8 The IMF and Social Protection, supra note 2; N. Wagner and J. Zhou, The IMF and Social Protection: Seven Advanced Economy Country Cases, Background Document No. BD/17-01/04 (5 July 2017), Independent Evaluation Office. 
The purpose of the International Monetary Fund (IMF) is to promote international monetary cooperation and stability through monitoring, lending and capacity development. These tasks put the IMF in the midst of discussions on macroeconomic performance. The Fund has also been characterised as the "single most influential international actor not only in relation to fiscal policy but also to social protection, even if both it and its critics might prefer that this were not the case". ${ }^{9}$ This statement not only recognises the importance of IMF policy-making for the development and sustainable financing of social protection frameworks, but also captures the profound scepticism that IMF social protection engagement meets. ${ }^{10}$

With social protection manifested as both an economic/development question as well as a question of human rights, approaches to social protection vary across international regimes. As a result social protection and its various embodiments, such as protection of vulnerable groups, are conceptually ambiguous and substantively contested. ${ }^{11}$ While social protection policies come in many forms, their common goal is to protect, and enhance the capacity of, in particular, the poor and vulnerable. ${ }^{12}$

Organisations that exercise public authority lend themselves to an assessment (or even control) of whether they are acting in an appropriate manner. ${ }^{13}$ In the context of international economic/financial organisations, this has often turned into a discussion on whether these organisations can be held accountable to human rights law. This question has been extensively explored and is not the interest of the present article as such. ${ }^{14}$ The impact of IMF

9 Report of the Special Rapporteur on extreme poverty and human rights, on the International Monetary Fund and its impact on social protection, UN Doc. A/HRC/38/33 (8 May 2018), para. 55 .

10 For a synthesis of the critique, see e.g., International Organizations clinic at NYU Law School, The IMF and Social Protection (2018).

11 See e.g., K. Brown, K. Ecclestone and N. Emmel, 'The Many Faces of Vulnerability', 16:3 Social Policy \& Society (2017) pp. 497-510.

12 Cf. e.g., the social protection policies in Annex I to The IMF and Social Protection (2017), supra note 2, p. 37 .

13 J. Klabbers, 'The Paradox of International Institutional Law', 5 International Organizations Law Review (2008) pp. 151-173, p. 172.

14 C. Tan, 'Mandating Rights and Limiting Mission Creep: Holding the World Bank and the International Monetary Fund Accountable for Human Rights Violations', 2:1 Human Rights \& International Legal Discourse (2008) pp. 79-116; O. de Schutter, 'Human Rights and the Rise of International Organizations: The Logic of Sliding Scales in the Law of International Responsibility', in J. Wouters et al. (eds.), Accountability for Human Rights Violations by International Organizations (Intersentia, Antwerp, 2010), 51-125; S. Skogly, Human Rights Obligations of the World Bank and the IMF (Cavendish Publishing, London, 2001); M. Darrow, Between Light and Shadow: The World Bank, The international Monetary Fund and International Human Rights Law (Hart Publishing, Oxford, 2003); W. van 
lending programs on the enjoyment of rights is also by now well documented, and acknowledged by the Fund itself. ${ }^{15}$ The adoption by financial institutions of social protection policies, however, is only beginning to attract academic attention. Through something of a social awakening, also the IMF seems to have gradually become more attuned to the social dimension of its policymaking. At the heart of the Fund's social protection engagement lies the importance of taking vulnerable groups into account.

The aim of the present article is to identify the emerging social protection interest in the IMF, and in particular to analyse the claim to protect vulnerable groups that is increasingly made as part of that development. ${ }^{16}$ The question of IMF engagement with protection of vulnerable groups has different aspects to it. First of all, it is of interest whom the IMF considers vulnerable. In order to put the IMF vulnerability endorsement in perspective, the article relates the concept of vulnerability as invoked by the Fund to a human rights-based approach. While human rights law does not constitute the only context for vulnerability discourse, the emerging conceptualisation of vulnerability in human rights law brings with it a claim to define what is good for the individual in the strongest available terms. ${ }^{17}$ Once individuals or groups can be identified as vulnerable under human rights law, such a recognition implies that there are corresponding duties that follow. The embeddedness of the protection of vulnerable groups in a human rights-based approach is manifested through human rights covenants, but also through acts of the International Labour Organization, and joint efforts such as the UN Social Protection Floor Initiative. ${ }^{18}$ As human rights law also constitutes the vocabulary through which much of the critique towards IMF policy-making is phrased, relating the two conceptions of protection of vulnerable groups to one another will also enable a discussion on their compatibility.

Genugten, The World Bank Group, the IMF and Human Rights: A Contextualized Way Forward (Intersentia, Antwerp, 2015).

15 E.g., the ex-post evaluation of Greece's 2010 Stand-By Arrangement recognises that the burden of adjustment was not equally shared: Independent Evaluation Office, The IMF and the Crises in Greece, Ireland, and Portugal: An Evaluation by the Independent Evaluation Office (8 July 2016), pp. 4-6; and International Monetary Fund, Greece: Ex Post Evaluation of Exceptional Access under the 2010 Stand-By Arrangement, IM F Country Report No. $13 / 156$.

16 One recent study exploring this 'turn' is e.g., C. Mariotti, N. Galasso and N. Daar, Great Expectations: Is the IMF Turning Words into Action on Inequality? (Oxfam International, 10 October 2017).

17 Paraphrasing M. Koskenniemi, 'Human Rights Mainstreaming as a Strategy for Institutional Power', 1:1 Humanity (2010) pp. 47-58.

18 ILO, 'R202 - Social Protection Floors Recommendation' (2012). 
However, the social protection engagement of the IMF also has an institutional aspect to it. A second main aim of the article is to analyse how vulnerability enters IMF policy-making. This requires identifying how vulnerability concerns enter into the different tasks of the IMF, but also to consider both the legal nature of those tasks, as well as their political impact. Through the increasing social protection engagement, the article claims, protection of vulnerable groups is becoming part of the law of the Fund. This can have some consequences for both the IMF as well as for its members. In fact, this way the IMF not only becomes a source for the identification of vulnerabilities, but also for implementing protection of vulnerable groups.

\section{Vulnerability as Prioritisation}

Human life is conditioned by vulnerability. We are all subject to bodily, psychological and socio-political vulnerabilities, as well as to the impact of our natural environment. Vulnerability, in this sense, is an inherent condition of being human in the world, and as such an ontological condition of all human existence. As part of this condition, vulnerability also follows from our exposition to the actions of others. ${ }^{19}$ In addition to being an inherent condition of life, the vulnerability concept has also become a tool for addressing enduring problems such as social marginalisation, inequality and economic insecurity, rendering it the "lingua franca of global and international justice". ${ }^{20}$

International law lacks a definition of vulnerability, and the concept as such is not explicit in core human rights conventions. ${ }^{21}$ In fact, even the language

19 C. Mackenzie, W. Rogers, and S. Dodds, 'Introduction: What is Vulnerability Theory and Why Does It Matter for Moral Theory?', in C. Mackenzie, W. Rogers, and S. Dodds (eds.), Vulnerability: New Essays in Ethics and Feminist Philosophy (Oxford University Press, New York, 2014), 1-29. On vulnerability as a universal condition, also see M. Fineman, 'The Vulnerable Subject and the Responsive State', 6o:2 Emory Law Journal (2010) pp. 251-276; and L. Peroni and A. Timmer, 'Vulnerable Groups: The Promise of an Emerging Concept in European Human Rights Convention Law', 11:4 International Journal of Constitutional Law (2013) pp. 1056-1085.

20 A. Cole, 'All of Us Are Vulnerable, but Some Are More Vulnerable than Others: The Political Ambiguity of Vulnerability Studies', 17:2 Critical Horizons (2016), 269-277, p. 263.

21 There are however some conventions where the concept is present such as the International Convention on the Protection of the Rights of All Migrant Workers and Members of Their Families, UN GA Res. 45/158 (18 December 1990), preamble; the Optional Protocol to the Convention on the Rights of the Child on the Sale of Children, Child Prostitution and Child Pornography, UN GA Res. 54/263 (25 May 2000), preamble, and Articles 8-10; and the International Convention for the Protection of All Persons from Enforced Disappearance, UN GA Res. 61/177 (20 December 2006), Article 7. 
used for referring to particular groups is inconsistent, a vulnerable status being expressed also through references to a state of marginalisation, disadvantage or underprivilege. Nevertheless, human rights law acknowledges the need for enhanced protection of particular groups. The International Covenant on Civil and Political Rights (ICCPR), for example, recognises special protection needs of women, persons deprived of liberty, legal aliens, persons charged with criminal offence and those convicted of a crime, children, children affected by discrimination, and ethnic and linguistic minorities, as well as, any other group of persons or their individual members, suffering discrimination. Conventions such as the Convention on the Elimination of All Forms of Discrimination against Women, the Convention on the Rights of the Child, the Convention on the Rights of Persons with Disabilities, and the International Convention on the Protection of the Rights of All Migrant Workers and Members of their Families, all grant enhanced protection to groups of persons facing particular challenges in their enjoyment of rights. ${ }^{22}$

For present purposes, out of the instruments of human rights law, the International Covenant on Economic, Social and Cultural Rights (ICESCR) stand out in particular, as it is the socio-economic focus at the heart of that convention that also constitutes the main contact point with IMF policy-making. The ICESCR underlines the importance of special protection for women and children in particular. In a range of General Comments and Concluding Observations, the Committee on Economic, Social and Cultural Rights has identified further groups, including: the elderly, persons with disabilities, migrants, persons deprived of their liberty, refugees, asylum seekers, internally displaced persons, slum dwellers, the Roma, indigenous peoples, ethnic minorities, persons living with HIV/AIDS, victims of natural disasters and persons living in poverty. ${ }^{23}$ However, the non-discrimination clause (ICESCR Article 2(2)) extends the special protection regime also to other groups of persons. While there are plenty of examples of groups that can be in a vulnerable position, it should be noted that the 2008 reporting guidelines leaves the definition of (disadvantaged and marginalised) groups to be made by the reporting state. ${ }^{24}$

22 For a comprehensive overview, see I. Nifusi-Sutton, The Protection of Vulnerable Groups under International Human Rights Law (Routledge, Abingdon, 2017) 20.

23 See ibid., for multiple references, concluding p. 148; also see A.R. Chapman and B. Carbonetti, 'Human Rights Protection for Vulnerable and Disadvantages Groups: The Contributions of the UN Committee on Economic, Social and Cultural Rights', 33:3 Human Rights Quarterly (2011) pp. 682-732.

24 Guidelines on Treaty-specific Documents to be Submitted by States Parties under Articles 1 and 17 of the International Covenant on Economic, Social and Cultural Rights (18 November 2008), UN Doc. E/C./12/2008/2 (2008); also ibid., pp. 687-69o. 
Also regional human rights instruments contain a number of provisions that apply to particular groups. In the European context the vulnerability concept has been explicitly invoked in a range of cases by the European Court of Human Rights, inter alia to grant protection to the Roma, persons with mental disabilities, people living with HIV and asylum seekers. ${ }^{25}$ In addition, several other groups are granted special protection in the European human rights framework, although not labelled explicitly as vulnerable, such as children and women, the poor and people living on social benefits. ${ }^{26}$ The European Social Charter likewise pay special attention to specific groups through underlining: equality between men and women (Article 4), socio-economic protection of children (Article 7) and the right of elderly to social protection (Article 23). The European Social Rights Committee has regarded pensioners as vulnerable because of their situation of dependence. This also applies to the situation of children and youth. ${ }^{27}$

The function of the vulnerability concept is not only to emphasise systemic deprivation of rights of particular groups, or to highlight the need of special protection measures. In addition, the vulnerability concept is layered, enabling the consideration of various degrees of vulnerability. ${ }^{28}$ This takes hold of the fact that vulnerable groups are diverse. Within vulnerable groups there may be 'particularly vulnerable' subgroups, whereas some broad groups, such as women, need not be considered vulnerable by default. ${ }^{29}$ In respect of discrimination, the vulnerability of applicants has been noted to function as a tool to single out the most disadvantaged sub-groups within the larger group. ${ }^{30}$

The European Court of Human Rights has for example recognised asylum seeking children as 'extremely vulnerable', ${ }^{31}$ whereas the European Committee of Social Rights has underlined that prioritisations also within vulnerable

25 Peroni and Timmer, supra note 19, p. 1057.

26 As to children and women, see F. Ippolito, '(De)Constructing Children's Vulnerability under European Law', in F. Ippolito and S.I. Sánches (eds.), Protecting Vulnerable Groups: The European Human Rights Framework (Hart Publishing, Oxford, 2015), 23-47; and F. Fines, 'European Protection for Women', in Ippolito and Sánches (eds.), ibid. 96-114; NifusiSutton, supra note 22, p. 240.

27 On the elderly in European law, see F. Seatzu, 'Reshaping EU Old Age Law in the Light of the Normative Standards in International Human Rights Law in relation to Older Persons', in Ippolito and Sánches (eds.), ibid., 49-70.

28 MacKenzie et al., supra note 19, p. 18.

29 See M.S.S. v. Belgium and Greece, Application no 30696/o9, European Court of Human Rights, 21 January 2011, paras 232 and 251. Valiulenè v. Lithuania, Application no. 33234/07, European Court of Human Rights, 26 March 2013, para. 69.

$30 \quad$ O.M. Arnardóttir, 'Vulnerability under Article 14 of the European Convention on Human Rights: Innovation or Business as Usual?', 4:3 Oslo Law Review (2017) pp. 150-171, p. 169.

31 ECtHR, Tarakhel v. Switzerland (4 November 2014) App. 29217/12, para 99. 
groups can be made, when the impact is not too big on "most vulnerable households" (in restricting pension rights). ${ }^{32}$ This means that not only is the vulnerability of a particular group always defined in casu, but also that the degree of vulnerability is assessed against the particular circumstances and sources of that vulnerability. In addition to prioritising particular groups vis-à$v i s$ those that are not in a vulnerable position, the concept of vulnerability serves to prioritise between competing claims to enhanced protection (to ensure protection of at least those deemed 'most vulnerable'). ${ }^{33}$ As a consequence, vulnerability also becomes an exclusionary device. ${ }^{34}$ This aspect of the vulnerability concept becomes particularly emphasised in situations of economic distress. ${ }^{35}$ In situations where a vulnerable status prioritises resources and social protection measures vulnerability becomes, in terms of international human rights law, part of the interpretation of the 'maximum available resources' doctrine. ${ }^{36}$ It is also precisely in such situations that states may be compelled to turn to the IMF.

A (Short) History of Social Protection in the IMF

The notion of vulnerability has entered IM F policy-making as part of a gradual move by the Fund towards recognising the social dimension of its policymaking. In the 1980s, with the establishment of the concessional facility for countries with balance of payments problems, poverty alleviation entered the IMF agenda, among other things, through the establishment of the Poverty

32 European Committee of Social Rights, xiv conclusions 2009, Finland. This argument was also raised by the Greek government in Decision on the merits: Federation of employed pensioners of Greece (IKA-ETAM) v. Greece, Collective Complaint No. 76/2012, para 67. M. Sepúlveda and C. Nyst, The Human Rights Approach to Social Protection (Ministry for Foreign Affairs of Finland, Helsinki, 2012) p. 38.

34 E.g., in the context of migration see C. Hruschka and L. Leboeuf, 'Vulnerability: A Buzzword or a Standard for Migration Governance?', Population Europe, Policy Brief No. 20 (January 2019).

35 The Guiding Principles on Human Rights Impact Assessments of Economic Reforms emphasise in particular the need to take into account the impact on most disenfranchised or marginalised individuals and vulnerable groups. Independent Expert on the effects of foreign debt and other related international financial obligations of states on the full enjoyment of all human rights, particularly economic, social and cultural rights, UN Doc. A/HRC/40/57 (19 December 2018).

$3^{6}$ R. Uprimny, S. Chaparro Hernández and A. Castro Araújo, 'Bridging the Gap. The Evolving Doctrine on ESCR and "Maximum Available Resources"', in K.G. Young, The Future of Economic and Social Rights (Cambridge University Press, Cambridge, 2019), 624-653, p. 653. 
Reduction Facility (now the Extended Credit Facility). ${ }^{37}$ By the second revision of the Articles of Agreement, the mandate of the IM F broadened with a reference to the social policies of the organisation's member states. While staff were not proscribed from addressing social issues, they were expected to exercise judgment as to whether social concerns are relevant for macroeconomic conditions and prospects. However, in the 1980 s and 9os such instructions were not yet built into operational guidelines. ${ }^{38}$ By the late 1990 s the Board supported inclusion of social safety nets and related conditionality in Fundsupported low-income country programmes. Yet, still at that time views were divergent among directors as to the desirability of such policies. ${ }^{39}$

Following a more general trend of organisations developing internal procedures for monitoring and assessment, ${ }^{40}$ the Fund has also developed a set of operational policies to assist in evaluating the impact of its decision-making. Perhaps the foremost example of this is the establishment of the Independent Evaluation Office (IEO). ${ }^{41}$ The establishment of a Poverty and Social Impact Analysis (PSIA) unit was in itself a result of a push from the IEO and reflected a growing awareness of a need to take into account and monitor the effects of Fund policies. ${ }^{42}$ Although the PSIA was disbanded in 2008, its tasks lived on with the Fiscal Affairs Department, providing input into IMF work on income distribution and poverty, social safety nets and public expenditure policy issues. ${ }^{43}$

In the aftermath of the 2008 crisis, the IMF Board agreed that Poverty Reduction and Growth Trust (PRGT)-supported programmes (that offer interest free financial support to low-income countries) should safeguard and, where possible, increase social spending. PRGT-supported programmes were therefore required to include explicit programme targets for "social and other

37 L.B. de Chazournes, 'The Bretton Woods Institutions and Human Rights', in W. Benedek et al. (eds.), Economic Globalisation and Human Rights (Oxford University Press, Oxford, 2007), 210-242.

38 The IMF and Social Protection (2017), supra note 2, p. 4.

39 A. Abrams, The IMF's Role in Social Protection: Fund Policy and Guidance, Background Document No. BD/17-01/o1 (5 July 2017), Independent Evaluation Office, p. 3.

$40 \quad$ De Schutter, supra note 14, p. 51.

41 De Chazournes, supra note 37, p. 235.

42 T. Reinold, "The Path of Least Resistence: Mainstreaming "Social Issues" in the International Monetary Fund', 31:3 Global Society (2016) pp. 392-416, p. 398.

43 The IMF and Social Protection (2017), supra note 2, p. 11. FAD provides policy and technical advice on public finance issues to the member countries. FAD economists take part in area department missions, review the fiscal content of Fund policy advice and adjustment programmes, and provide direct advice to member countries on public finance issues. 
priority spending". ${ }^{4}$ In 2009, the IMF became a collaborating agency in the UN Social Protection Floor Initiative that promotes universal access to essential social transfers and services (the goal of which is to alleviate poverty, vulnerability and social exclusion). ${ }^{45}$

Social protection has become prominent also in statements by IMF management, for example Christine Lagarde stating that "reducing excessive inequality ... is not just morally and politically correct, but it is good economics", further underlining the importance of inclusiveness for macroeconomic performance both in terms of income and gender, access to education and employment and climate-related issues. ${ }^{46}$ The IEo has found widespread involvement of the IMF in social protection (albeit with cross-country variation), in some cases even characterised as relatively deep engagement. ${ }^{47}$ Also external research confirms a trend of increased emphasis on social spending. ${ }^{48}$ The 2018 Review of Program Design and Conditionality notes that social expenditure has been increasingly protected in Fund-supported programmes, and that social spending targets have been reached to a comparable level to other programme targets. While admitting that there is room to improve the quality of social spending, the review recommends increasing the focus on the impact of programme policies on poor and vulnerable groups even further. ${ }^{49}$

IMF social protection engagement peaked in June 2019 with the adoption of the Strategy for IMF Engagement on Social Spending. The strategy makes clear that social spending, defined as social protection, health and education spending, is a key policy lever for, inter alia, promoting inclusive growth, addressing inequality, and protecting vulnerable groups. Distributional objectives, in other words, are to be seen as compatible with economic growth..$^{50}$ The way in which the IMF refers to social safeguards, as measures to protect the level of social spending for example through spending floors on health and education,

44 J. Klugman et al., 'The ImF and Social Protection: Seven Low-Income Country Cases', Independent Evaluation Office Background Document No. BD/17-01/o6, 5 July 2017, p. 4; International Monetary Fund, Guidance Note on IMF Engagement on Social Safeguards in Low-Income Countries (11 July 2018) p. 6.

45 The IMF and Social Protection, supra note 2, p. 6. See e.g., ILO, Social Protection Floor Initiative (SPF-I) Factsheet, 2015.

46 C. Lagarde, 'Lifting the Small Boats' (17 June 2015), speech, IMF, https://www.imf.org/en/ News/Articles/2015/og/28/04/53/spo61715.

47 The IMF and Social Protection, supra note 2.

48 Ibid., p. 46; Mariotti et al., supra note 16.

49 International Monetary Fund, 2018 Review of Program Design and Conditionality, Policy Paper No. 19/012 (20 May 2019), pp. 23-24.

5o International Monetary Fund Policy Paper (no. 19/o16), A Strategy for IMF Engagement on Social Spending (14 June 2019) p. 13 (hereafter Social Spending Strategy). 
as measures to protect vulnerable groups and as reforms that strengthen and expand social safety nets, has been noted to bear resemblance to the World Bank's conception of social protection. ${ }^{51}$ This is perhaps not that surprising, given that the IMF policy in respect of incorporating social protection considerations is to rely on the expertise of other institutions (mainly the World Bank).52

The main purpose of the IMF, as defined in the Articles of Agreement, is to ensure the stability of the international monetary system (including exchange rates and international payments), and to facilitate the expansion and balanced growth of trade. ${ }^{53}$ In pursuit of these purposes, the IMF basically performs three main tasks: surveillance, provides financial assistance and capacity development (technical advice), in all of which social protection issues can arise. In-between surveillance and lending, as the two main tasks of the IMF, vulnerability concerns enter slightly differently. The key instruments that guide Fund social protection engagement in performing these functions are the Integrated Surveillance Decision and the associated 2015 Guidance Note for Surveillance under Article IV Consultations, and the 2014 Revised Operational Guidelines to IMF staff on the 2002 Conditionality Guidelines. ${ }^{54}$

$51 \quad$ International Monetary Fund, Social Safeguards and Program Design in PRGT and PSI-Supported Programs, (6 June 2017) p. 6; A. Broome, 'Rethinking austerity? The IMF and social safeguards', European Politics and Policy Blog: <http://blogs.lse.ac.uk/ europpblog/2017/08/07/rethinking-austerity-the-imf-and-social-safeguards/>, visited 6 September 2018.

52 Heavily underlined e.g., in the Social Spending Strategy, supra note 50. The IMF Independent Evaluation Office has considered social protection as a policy that encompass a variety of instruments providing cash or in-kind benefits to vulnerable individuals or households, including: social insurance (e.g., public pension schemes), social assistance (such as transfers to the poor), and labour market interventions for the unemployed (such as unemployment insurance and active labour market policies). The IEO also notes that social protection can include other policies that have social protection elements, such as price subsidies for staple foods and energy. The IMF and Social Protection, supra note 2.

53 International Monetary Fund Articles of Agreement, Article I(ii). In 2007, the Fund's Executive Board formally interpreted "a stable system of exchange rates" in Article IV, Section 1 to mean "systemic stability". IMF, Modernizing the Legal Framework for Surveillance: An Integrated Surveillance Decision, Revised Proposed Decision (17 July 2012).

54 Statement by the Managing Director on the Independent Evaluation Office Report on the $I M F$ and Social Protection Executive Board Meeting (19 July 2017). Decision on Bilateral and Multilateral Surveillance (18 July 2012), Guidance Note for Surveillance under Article IV 
The IMF undertakes surveillance principally through 'Article IV' consultations with individual countries, whereas member states provide the Fund with necessary information for the surveillance. ${ }^{55}$ The range of issues that can be included in Article IV consultation has increased dramatically. ${ }^{56}$ Surveillance addresses medium term challenges and can for that reason raise social issues, as long as they can be regarded as crucial from a macroeconomic perspective. 'Macro-criticality' serves as the threshold that links the policy pursued to the purposes and tasks of the IMF, hereby legitimising Fund engagement. Attention can be given to particular groups such as women, when for example disempowerment is perceived to have an impact on the macroeconomic performance of a country. ${ }^{57}$

The purpose of lending is to assist countries that face economic crises through financial support. The IMF has various lending instruments at its use, tailored to different types of needs and country specific circumstances. ${ }^{58}$ Typically, a country's government and the IMF must agree on a programme of economic policies before the IMF grants a loan. While IMF member states have a right to lend money from the organisation, lending becomes an issue in particular when there is a balance of payments problem. In order for the lending state to be able to repay its loan, it needs to achieve fiscal stability. ${ }^{59}$ For this reason the lending arrangement specifies the economic policies and

Consultations (19 March 2015) (hereafter Guidance note for Surveillance) and the Revised operational guidelines to IMF staff on the 2002 conditionality guidelines (August 2014) (hereafter Conditionality Guidelines)).

55 International Monetary Fund Articles of Agreement (Article IV, Section 3(b)).

56 Darrow, supra note 14, pp. 34-35.

57 See e.g., International Monetary Fund Country Report No. 17/242 on Japan (July 2017).

$5^{8}$ The IMF provides loans at non-concessional interest rates and loans provided to poorer countries on concessional terms, with interest rates that are low or in some cases zero. Low-income countries may borrow on concessional terms through facilities available under the Poverty Reduction and Growth Trust (PRGT). The IMF's instruments for nonconcessional loans are Stand-By Arrangements (SBA); the Flexible Credit Line (FCL); the Precautionary and Liquidity Line (PLL); for medium-term needs, the Extended Fund Facility (EFF); and for emergency assistance to members facing urgent balance of payments needs, the Rapid Financing Instrument (RFI). Out of these, Flexible Credit Line (FCL) does not have conditionality as it is only available for countries with a track record of implementing policy advice. Historically, for emerging and advanced market economies in crises, the bulk of IMF assistance has been provided through Stand-By Arrangements (SBAs). See IMF Annual Report 2017, and IMF Factsheet: IMF Lending, March 2016.

59 G. Bianco and F. Fontanelli, 'Enhancing the International Monetary Fund's Compliance with Human Rights - The Issue of Accountability', in J.P. Bohoslavsky and J.L. Černič (eds.), Making Sovereign Financing and Human Rights Work (Hart Publishing, Oxford, 2014), 213-232, p. 225. 
measures that a country agrees to implement to resolve its balance of payments problem. ${ }^{60}$

As a general rule, the higher the loan relative to the quota of the requesting country, the tougher the conditions imposed. IMF policies also differ somewhat in respect of whether the lending country is a low-income country or an advanced economy. ${ }^{61}$ Low-income countries can also have strong incentives to implement Fund policy as a precondition for aid and foreign direct investment. ${ }^{62}$ This invests the Fund with an authoritative position in respect of such countries. The position of the IMF in the negotiations becomes even further amplified in times of financial crises. However, as the example of Iceland demonstrates, negotiations need not always be a one-directional process. ${ }^{63}$

Since 2009 a "social and other priority spending" target has been required in low-income country programmes. These include minimum floors for social spending, and specific measures to protect vulnerable groups. ${ }^{64}$ IMF statistics display a rising trend of including spending floors in country programmes. ${ }^{65}$ These floors can include spending on health, education and social safety nets. ${ }^{66}$ In these cases, the IMF sets a social spending target as a condition for the loan. This way also the protection of vulnerable groups can become part of conditionality. However, the more immediate the needs of a country, the more social protection becomes an issue of coping with the social impact of the adjustment measures included in the programme. In lending, vulnerability concerns therefore also enter as a way of mitigating the effect of other programme

6o This programme is presented to the Fund's Executive Board in a Letter of Intent and further detailed in a Memorandum of Understanding.

61 The IMF advocacy role tending to be stronger in respect of low-income countries. The IMF and Social Protection, supra note 2, pp. 20 et seq.

62 Darrow, supra note 14, p. 35.

63 Iceland managing to secure IMF loan although not adhering to the initial IMF programme. Gudmundur Árnason, Permanent Secretary of the Ministry of Finance of Iceland, presentation at $2018 \mathrm{IMF}$ and World Bank Spring Meetings, available at <https:// www.brettonwoodsproject.org/2018/04/lost-decade-human-rights-assessing-austerity -alternatives-10-years-financial-crisis/>, visited 29 August 2019, and The IMF and Social Protection, supra note 2, p. 22, para. 46.

64 Guidance Note on IMF Engagement, supra note 44, p. 6. For example, Jamaica's 2013 EF F arrangement and 2016 sBA included floors on social spending, which were all met. In addition, programme documents discussed in detail the authorities' commitment to reduce the adverse impact of adjustment on vulnerable groups by improving the existing social protection framework. International Monetary Fund, 2018 Review of Program Design and Conditionality, International Monetary Fund Policy Paper No. 19/o12, (20 May 2019).

65 S. Gupta, M. Schena, and S.R. Yousefi, Expenditure Conditionality in IMF-Supported Programs, IMF Working Paper WP/18/255 (7 December 2018) p. 22.

66 Social Spending Strategy, supra note 5o, p. 8. 
measures. The Conditionality Guidelines incorporates this explicitly by stating that: "if feasible and appropriate, any adverse effects of program measures on the most vulnerable should be mitigated". 67

\section{5}

Who Defines Vulnerable Groups?

The point of departure of the IMF approach to vulnerable groups is that such groups are defined in a country specific context, and that states are the primary source for the identification of vulnerable groups. The Conditionality Guidelines assert as general guiding principles: the national ownership of programmes; that any assessment of a member's policies and IMF advice shall take into account the circumstances of the member; take into account other objectives of the member state; and respect domestic and social policies. ${ }^{68}$ States, in other words, have the prerogative to define what should be included in "social and other priority spending". ${ }^{69}$ This renders the identification of vulnerable groups not only subject to circumstances of individual countries, but also to their political and ideological preferences. ${ }^{70}$

The domestic ownership of social spending is well in line with the approach of the human rights regime. For example in respect of protection floors both the CESCR and International Labour Organization (ILO) Recommendation 202 on social protection floors depart from the idea that such floors are nationally defined. ${ }^{71}$ As to the IMF, domestic authorities and country teams have flexibility in defining the programme targets narrowly or more broadly - only on social spending or on social and other priority spending combined - depending on country circumstances, and in accordance with national Poverty Reduction Strategies/Economic Development Documents. ${ }^{72}$ Although the final decision

$67 \quad$ Conditionality Guidelines, supra note 54, p. 3.

68 Decision on Bilateral and Multilateral Surveillance, supra note 54.

69 Social Safeguards and Program Design in PRGT and PSI-Supported Programs, supra note 51, p. 14.

70 An aspect often ignored in social protection literature. For an illustration, see L. Luccisano and L. Macdonald, 'Mexico and social provision by the Federal Government and the Federal District: obstacles and openings to a social protection floor', 14:3 Global Social Policy (2014) pp. 333-351.

71 The Committee on Economic, Social and Cultural Rights, Social protection floors: an essential element of the right to social security and of the sustainable development goals, UN Doc. E/C.12/2015/1 (15 April 2015), para. 1; and ILO, Recommendation concerning National Floors of Social Protection, 2012 (No. 202) (14 June 2012).

72 Or, medium-term poverty reduction and growth objectives and policies as outlined in the programme documentation, see Abrams, supra note 39, p. 7; Klugman et al., supra note 44, p. 4. 
on the use of Fund resources is made by the Executive Board, that decision is preceded by staff-level agreements as manifestations of an understanding between the staff of the IMF and the authorities of a member country on a programme. In fact, programmes are hardly ever voted down by the Board. ${ }^{73}$

Through surveillance, the IMF has somewhat more leeway to give targeted advice for example concerning youth unemployment or gender issues, as long as such concerns are crucial to the macroeconomic performance of the state. The responsibility is upon staff to determine the extent to which an issue is macro-critical and whether the IMF has the expertise to analyse it or provide policy advice. Country teams are instructed to take into account country circumstances, to make prioritisations, and to "exercise judgment in selecting issues for in-depth coverage. ${ }^{74}$ Staff should also prioritise social spending with greatest impact on vulnerable groups, as well as to decide on the best means of protecting that group. ${ }^{75}$ This underlines the crucial role of staff as gatekeepers for protection concerns to enter IMF policy-making. ${ }^{76}$

\section{Who Is Considered Vulnerable?}

As noted above, vulnerable groups are as a point of departure defined in country specific contexts. ${ }^{77}$ In a Factsheet on Protecting the most vulnerable under IMF-supported programmes (March 2016), examples of how IMF supported programmes seek to protect social spending mentions: gender equality, access to health and education, pro-poor spending, access to water and electricity (Rwanda); poverty reduction, health and education, basic social services (Solomon islands); Minimum income, youth and long-term unemployment, health care (Greece); and mitigation of electricity tariff reform and fuel subsidies

73 The decision-making and guidance role of the Executive Board has by the IEo been noted to have been minimal for example in the Euro area crisis. See M. de Las Casas, The IMF Executive Board and the Euro Area Crisis - Accountability, Legitimacy, and Governance, Independent Evaluation Office Background Paper, BP/16-o2/o2 (8 July 2016). For a political view of IMF decision-making, see M. Breen, The Politics of IMF Lending (Palgrave, Basingstoke, 2013).

74 Guidance Note for Surveillance, supra note 54, para. 75, figure 3, p. 36, Box 1, and para. 76 .

75 Social Spending Strategy, supra note 5o, p. 33.

76 It is also for this reason that the newly adopted Social Spending Strategy is to be complemented with a staff guidance note in 2020 .

77 For example Sierra Leone in its Poverty Reduction Strategy Paper identified a long list of vulnerable groups, which relate to the history of civil war (amputees, widows and female single parents, widowers, unmarried single girl/mothers, the aged or elderly, street children, children in conflict with the war, homeless, polio victims, slum dwellers, orphans, discharged prisoners and children prisoners). Sierra Leone, Poverty Reduction Strategy Paper, International Monetary Fund Country Report No. 05/191 (June 2005). 
removal effects for the poor and low-income households (Jordan). ${ }^{78}$ Recent studies by the IEO and the IMF enable the identification of some commonly identified groups. These include in particular the poor, elderly, youth and women. ${ }^{79}$ Also the 2019 Strategy on Social Spending, while avoiding lists of groups who should be given particular attention, does mention the elderly, women and youth in the context of spending pressures, whereas mitigating programme impact on the poor and poverty reduction are core themes of the strategy at large. ${ }^{80}$

The emphasis on vulnerable groups also shows some variation according to the economic welfare of the country. Poverty reduction is a core objective of IMF programmes especially in low-income countries. The 2009 reform of the Poverty Reduction and Growth Trust called to support policies that safeguard and increase social and other priority spending. These policies may look different. In some cases, poverty reduction programmes seek to shift expenditures toward social programmes. In other cases the goal is to adopt specific measures that safeguard poor and vulnerable groups from fiscal adjustment and reform measures. ${ }^{81}$ The first of these are often defined to cover total spending for example on health and education, and therefore not specifically geared towards vulnerable groups. ${ }^{82}$

In respect of the poor, the IMF has preferred targeting the poor in particular, instead of providing general prize subsidies of basic commodities such as food and fuels, as such general subsidies often tend to leak benefits also to the non-poor. ${ }^{83}$ Low-income country programmes in particular have been noted to increasingly include an explicit floor on poverty-reducing social expenditures. ${ }^{84}$ When for example reducing energy price subsidies, IMF staff is reported to have paid particular attention to the social implications and suggested mitigating measures for the poor. In addition, gender inclusion has been a recurring theme. ${ }^{85}$

78 Protecting the Most Vulnerable under IMF-supported Programs, $<$ https://www.imf.org/ / media/Files/Factsheets/English/ImfprotectPoor.ashx>.

79 See e.g., Social Safeguards and Program Design in PRGT and PSI-Supported Programs, supra note 51, p. 6.

8o Social Spending Strategy, supra note 5o, p. 9.

81 Ibid., p. 1.

$82 \quad$ Ibid., p. 14 .

83 Ibid., Box 6, p. 35 .

84 The IMF and Social Protection (2017), supra note 2, p. 21.

85 Social Safeguards and Program Design in PRGT and PSI-Supported Programs, supra note 51. A. Feltenstein, Subsidy Reforms and Implications for Social Protection: An Analysis of IMF Advice on Food and Fuel Subsidies, Independent Evaluation Office Background Paper (BP/17-01/02) (5 July 2017). 
As to emerging market countries, a recent study indicates that the Fund, when seeking to mitigate the impact of adjustment measures, has underlined allocation to social programmes/social safety net spending in general (such as education, health, nutrition), but also called for better targeting of social spending, implying that social protection should better benefit those who need it the most. Examples display an emphasis on the poor and particular segments of the poor (such as poor households or poor pensioners), lowestwage employees and the unemployed..$^{86}$

As to advanced economies, protection of the poor and reduced income inequality (United States) and gender inclusiveness (Japan) have been pursued as long-term objectives in IMF social protection advice/recommendations. ${ }^{87}$ In respect of Ireland, the IMF has emphasised the importance of intergenerational fairness for the youth and the protection of the poor in better targeting welfare benefits. Support has also found to be needed for "economicallyvulnerable homeowners". 88 For example in respect of Portugal, the youth as well as those earning the lowest wages and pensions were granted special attention. For youth, focus was on unemployment, whereas the poor were considered in particular need of targeted welfare benefits. ${ }^{89}$ Whereas in Iceland and Japan distressed or low-income households were considered particularly vulnerable, in the case of Cyprus social fallout stands out as a major concern. Characteristic of the IMF approach, however, these groups are not treated similarly in their entirety. In the context of Ireland for example, there was a strong emphasis on means testing of taxation of child benefits, support to lowincome families and the elderly. ${ }^{90}$ In respect of Greece, low-income retirees was a group recognised as particularly vulnerable already early on in IMF programmes. $^{91}$

All of the groups identified above - poor, elderly, youth and women - are also well acknowledged as potentially vulnerable groups in international human rights law. Article 3 of the ICESCR defines a general obligation to secure

86 L.H. Tan and M. Selowsky, The IMF and Social Protection: Seven emerging market country cases, Background Document No. BD/17-01/05 (5 July 2017) (Independent Evaluation Office), studying the Dominican Republic, El Salvador, Romania, Latvia, Morocco, Tunisia and Malaysia.

87 Wagner and Zhou, supra note 8.

88 International Monetary Fund Country Report No. 10/209, Ireland: 2010 Article IV Consultation - Staff Report (18 June 2010) p. 20.

89 See Wagner and Zhou, supra note 8, pp. 20-27.

9o Ibid., p. 26.

91 International Monetary Fund Country Report No. 10/110, Greece: Staff Report on Request for Stand-By Arrangement (10 May 2010), pp. 11-12. Also see e.g., M. Soto, V. Thakoor, and M. Petri, Pension Reforms in Mauritius: Fair and Fast - Balancing Social Protection and Fiscal Sustainability, IMF Working Paper WP/15/126 (19 June 2015). 
economic and social rights equally to men and women..$^{92}$ Article 10(3) provides that states should take special protective measures in respect of children and young persons. While that article is mainly concerned with child labour, youth is identified as a separate group in General Comment 18, which underlines protection of women and youth in relation to the right to work. Elderly and lowincome groups are granted special protection for example in respect of the right to housing (General Comment 4), ${ }^{93}$ an issue that also the IMF has ventured into (for example in respect of Ireland as a point of reform of the social security system). ${ }^{94}$ General Comment 6 specifically takes hold of the implementation of the CESCR in respect of older persons in order to ensure them adequate protection. Low-income elderly are considered among the most vulnerable in society, as are older women. ${ }^{95}$

General Comment 12 on the right to adequate food affirms that vulnerable groups such as the impoverished, young children and older persons may need special protection, and in respect of right to water (General Comment 15) women and elderly are underlined in particular. As to the right to health, General Comment 14 states that special obligations exist inter alia in respect of women, adolescents and older persons, but also further states that access to healthcare shall be ensured for vulnerable groups without discrimination of any kind. General Comment 19 on the right to social security identifies core obligations that are to be secured without discrimination, and with a particular attention to women and the rights of the most marginalised and disadvantaged. Persons living in poverty are generally considered to belong to the most disadvantaged and marginalised. ${ }^{96}$

The one principle that has been found to have the greatest potential to protect vulnerable groups in human rights law is non-discrimination. General Comment 20 on non-discrimination notes that sex is an explicit ground of discrimination, whereas implied grounds include also youth and poverty. ${ }^{97}$ Discrimination is mainly present in IMF work, in those terms, as an issue of

92 Equal rights of men and women are elaborated further in General Comment 16, detailing how states should ensure that women enjoy equal rights, CESCR General Comment No. 16: The Equal Right of Men and Women to the Enjoyment of All Economic, Social and Cultural Rights (Art. 3 of the Covenant) (E/C.12/2005/4) (11 August 2005).

Also see Nifusi-Sutton, supra note 22, pp. 128-129.

94 Wagner and Zhou, supra note 8.

95 Nifusi-Sutton, supra note 22, pp. 139-140.

96 Ibid., p. 138.

97 CESCR, General Comment No. 20:Non-discrimination in economic, social and cultural rights (art. 2, para. 2, of the Covenant) (E/C.12/GC/20) (2 July 2009). 
gender equality, and has as such been addressed in several policy instruments, as well as endorsed by the Managing Director, as "not just the right thing to do" but also because it can "transform societies and economies for the good of all".98

There is no exhaustive definition of vulnerable groups, and given the contextual nature of the vulnerable condition, there never can be. Nevertheless, when contrasting the concept of vulnerability as invoked in IMF policy-making with the identification of vulnerable groups in international human rights law, several groups can be found that seem to escape the attention of the IMF (apart from the possibility of mitigating the impact of particular programme effects).

By way of examples two groups can be mentioned. Refugees/migrants/ asylum-seekers are one group in point recognised in need of special protection in human rights law. While IMF discussion notes have noted the humanitarian dimension of migratory/refugee flows, Fund emphasis is on the macroeconomic impact of such flows on the receiving state. The vulnerability of refugees as such is therefore not addressed, but rather their workforce integration, long-term benefits of counteracting the economic impact of the demographic transition and helping states to cope (especially in the MENA region). ${ }^{99}$

Another group that enjoys special protection in human rights law but escapes the operative perspective of the IMF is children. Both the ICCPR (Article 24(1)) and the ICESCR (Article 10(3)) pay special attention to children. Above all, the Convention on the Rights of the Child establishes a special regime for the protection of children as a group. ${ }^{100}$ It also contains some provisions

98 E. Solberg and C. Lagarde, 'It's Time to Let Women Thrive', Project Syndicate, 24 January 2018, https://www.project-syndicate.org/commentary/women-labor-force-participation -by-erna-solberg-and-christine-lagarde-2018-o1?barrier=accesspaylog.

99 S. Aiyar et al., The Refugee Surge in Europe: Economic Challenges, IMF Staff Discussion Note (sDN 16/02) (January 2016), B. Rother, The Economic Impact of Conflicts and the Refugee Crisis in the Middle East and North Africa, International Monetary Fund Staff Discussion Note (SDN 16/o8) (16 September 2016).

100 Children's particular vulnerability has been expressed by the Committee on the Rights of the Child: "At a universal level all children aged o-18 years are considered vulnerable until the completion of their neural, psychological, social and physical growth and development". Committee on the Rights of the Child, General Comment No. 5 on general measures 
for children in specific situations, such as for children with disabilities and asylum-seeking children. ${ }^{101}$ The Committee on the Rights of the Child has in its General Comments and Concluding Observations drawn attention to children in vulnerable situations. General Comment 19 (on public budgeting for the realisation of children's rights), for example, states that allocation and expenditure of financial resources by states should ensure in particular the rights of children in vulnerable situations. ${ }^{102}$

The special position of children in international human rights law derives from the physical characteristics that make children 'inherently' vulnerable. ${ }^{103}$ It is also well acknowledged that women and children bear the heaviest burden of extreme poverty and deprivation. ${ }^{104}$ Yet children are mainly present in IMF policy-making as a question of promoting equal access to the labour market and gender equality. ${ }^{105}$ Illustrative of the Fund approach, in respect of child labour there are studies indicating that a ban on child labour may worsen the economy of particular states, unless accompanied by other measures. ${ }^{106}$ The vulnerable position of children as such is only touched upon in occasional

of implementation of the Convention on the Rights of the Child, UN Doc. $\mathrm{CRC} / \mathrm{GC} / 2003 / 5$ (3 October 2003), para. 72.

101 K. Sandberg, 'The Convention on the Rights of the Child and the Vulnerability of Children', 84:1 Nordic Journal of International Law (2015) pp. 221-247, p. 223. A neat example of where gender and migration issues meet, is IMF Country Report No. 17/242 on Japan from July 2017 , where the IMF is notes that a rapidly aging population and shrinking labour force are hampering growth and productivity. Measures to boost female and older-worker labor force participation and to allow more use of foreign workers and their integration in the economy are seen as crucial to compensate for the shrinking Japanese working-age population.

102 Committee on the Rights of the Child, General Comment No. 19 on public budgeting for the realization of children's rights (Art. 4), UN Doc. CRC/C/GC/19 (20 July 2016).

103 Ippolito, supra note 26.

104 See e.g., I. Ortiz, J. Chai and M. Cummins, Austerity Measures Threaten Children and Poor Households: Recent Evidence in Public Expenditures from 128 Developing Countries, UNICEF Social and Economic Policy Working Paper Number 2011-09, UnICEF Department Policy and Practice (2011).

105 See e.g., Guidance Note for Surveillance, supra note 54, Box 8, p. 40; Germany: Staff Concluding Statement of the 2018 Article IV Mission (14 May 2018).

106 R.C. Barnett and M.A. Espinosa-Vega, Monetary and Financial Systems Department Barriers to Capital Accumulation and the Incidence of Child Labor, International Monetary Fund Working Paper (WP/05/220) (November 2005). 
working papers and studies, ${ }^{107}$ or in country specific poverty reduction strategy papers. ${ }^{108}$

None of this is to say that IMF policies could not come for the benefit of children. As IMF social spending is defined as social protection, health and education spending, securing (or even improving) access to healthcare, education and childcare, not to mention a generally improved level of social protection, it comes for the benefit of children as well. ${ }^{109}$ Spending floors can be included in specific country programmes that protect children in particular. ${ }^{110}$ Children are also present as an aggravating factor, increasing the probability of poverty of particular groups of society, and as such warranting special attention. ${ }^{111}$ Nevertheless, to portray children as 'macro-critical' in the IMF operational perspective seems currently more difficult than for example for the elderly or women.

107 For example noting that the presence of IMF conditionality decreases the protective effect of parents' education on child malnourishment. I. de Carvalho Filho, Household Income as a Determinant of Child Labor and School Enrollment in Brazil: Evidence from a Social Security Reform, International Monetary Fund Working Paper (WP/o8/241); A. Daouda et al., Impact of International Monetary Fund programs on Child Health, 114(25); Proceedings of the National Academy of Sciences of the United States of America (2017); Barnett and Espinosa-Vega, ibid.

108 See e.g., Sierra Leone Poverty Reduction Strategy paper, supra note 77, that even explicitly refers to the fulfilment of the human rights of children. It should be noted that the Social Spending Strategy does also mention children (along with disabled) although only in a footnote, supra note 5o, p. 3, note 1.

109 D. Coady et al., Targeting of Transfers in Developing Countries: Review of Lessons and Experience, 76 The World Bank (2004); IMF and Social Protection (2018), supra note 10, p. 81.

110 See International Monetary Fund, World Regional Economic Outlook, Sub-Saharan Africa:Domestic Revenue Mobilization and Private Investment, (April 2018) p. 27; International Monetary Fund, Country Report No. 18/297, Argentina: First Review under the Stand-By Arrangement; Inflation Consultation; Financing Assurances Review; and Request for Rephasing, Augmentation, Waivers of Nonobservance and Applicability of Performance Criteria, and Modification of Performance Criteria-Press Release; Staff Report; and Staff Supplement (26 October 2018). Klugman et al., supra note 44, also have many examples. Also see Guidance Note on IMF Engagement, supra note 44, p. 6. Incidentally, protection floors are by the ILO promoted as particularly important for preventing child labour. International Labour Office, World Report on Child Labour: Economic vulnerability, social protection and the fight against child labour (2013), pp. 59-6o.

111 Social Spending Strategy, supra note 50, p. 31. 
Apart from the situation where vulnerability serves to focus mitigating efforts on particular segments of society, IMF engagement with particular social groups requires that a link can be established between that group and the macroeconomic performance of the state. According to the Guidance Note for Surveillance, surveillance should cover all member's policies that affect the member's economic stability. This always includes exchange rate, monetary, fiscal and financial sector policies. Other policies should be assessed if they are macro-critical, that is, if they affect the financial stability of the country. While the Guidance Note states that potentially macro-critical structural issues cannot be exhaustively defined, a structural issue has been deemed macro-critical if it affects, or has the potential to affect, domestic or external stability. The Guidance Note identifies by way of examples jobs and growth, infrastructure, labour markets, social safety nets, public sector enterprises, governance, gender and climate change. ${ }^{112}$ Job creation and growth are at the centre of surveillance in low-income countries in particular. Further, macrocritical social issues such as poverty reduction, economic inclusion, human capital development and macro-critical governance issues should receive particular attention. ${ }^{113}$

The Strategy on Social Spending establishes that a particular social spending issue is considered macro-critical if that spending is not sustainable, adequate for inclusive growth and protecting the vulnerable or efficient. ${ }^{114} \mathrm{~A}$ judgment that a condition is of critical importance "means that if it was not implemented, it is expected that the goals would not be achieved or that program monitoring would not be possible". 115 All critical measures generally must have conditionality associated with them. On the other hand, staff must avoid setting conditions on measures "that may be desirable, but that are not critical for achieving the program goals or for monitoring implementation of those goals". ${ }^{116}$ In effect, this prevents staff from setting conditions that would promote social protection, if such protection cannot be defined as crucial for the achievement of the economic goals of the programme. Criticality, in other

112 Guidance Note for Surveillance, supra note 54, para. 75. See e.g., International Monetary Fund Country Report No. 17/181, Norway, Selected Issues (July 2017), where the IMF analysed the gender dimension of the economy upon request by Norway.

113 Guidance Note for Surveillance, supra note 54, para. 11.

114 Social Spending Strategy, supra note 50, p. 23.

115 Conditionality Guidelines, supra note 54, p. 9.

116 Ibid., p. 10. 
words, is always defined with reference to the achievement of programme goals and the monitoring of programme implementation. ${ }^{117}$

Out of the vulnerable groups identified above, macro-criticality is fairly well established in respect of the poor, elderly and gender equality. A focus on the poor enters first of all as a poverty reduction question for low-income countries. The Guidance Note on Surveillance explicitly states that poverty is one of the issues that is to be addressed in accordance with the macro-criticality principle. ${ }^{118}$ In respect of the elderly, IMF engagement with pension reform issues has been widely explored. The design of the pension system of any country and its financial viability is seen as macro-critical because of the implications for allocation and the economy at large. The question is also predicted to become ever more important due to the ageing population. As the replacement rate will potentially drop in coming decades in many countries, this development also threatens to push elderly into poverty. ${ }^{119}$

The link between gender equality and economic performance is by now also well established. Although gender may by IMF Management still be described as an "emerging macro critical" issue, ${ }^{120}$ others go as far as to call the IMF a "global leader" in highlighting inequality. ${ }^{121}$ Along with a recognition that inequality is associated with less sustained growth (as well as other risks), the IMF has increasingly been promoting gender-responsive budgeting. ${ }^{122}$ Gender issues have also been included in conditionality (for example in respect of Jordan, Egypt and Niger). ${ }^{123}$ Commonly gender concerns enter as a labour force participation issue. However, it can also be addressed as a question of access to finance. ${ }^{124}$ Research on the macro-economic dimension of gender issues culminated in the inclusion of gender in the Guidance Note for Surveillance as one of the structural issues IMF "staff may wish to consider" when developing

117 Abrams, supra note 39 .

118 Guidance Note for Surveillance, supra note 54, para. 11.

119 P.S. Heller, The IMF's Involvement with Pension Issues: 2006-2015, Independent Evaluation Office, pp. 1-2. Replacement rate is the percentage of a worker's pre-retirement income that is paid out by a pension programme upon retirement.

120 Statement by the Managing Director on the Independent Evaluation Office Report on the IMF and Social Protection Executive Board Meeting (19 July 2017).

121 Mariotti et al., supra note 16, p. 2.

122 A.G. Berg and J.D. Ostry, Inequality and Unsustainable Growth. Two Sides of the Same Coin? IMF Staff Discussion Note, (sDN/11/o8) (8 April 2011) sDN/11/o8; M. Newiak, and T. Zeinullayev, Catalyst For Change: Empowering Women and Tackling Income Inequality, International Monetary Fund Staff Discussion Note (sDN/15/20) (October 2015).

123 International Monetary Fund, How to Operationalize Gender Issues in Country Work, Policy Paper, (1 June 2018) p. 13 .

124 C. Deléchat et al., What is Driving Women's Financial Inclusion across Countries?, International Monetary Fund Working Paper (WP/18/38) (March 2018). 
surveillance reports. ${ }^{125}$ In June 2018, the IMF released a 'How-To' note on Operationalising Gender Issues in Country Work, which affirms that country teams should cover gender issues where they are deemed macro-critical or when requested by the authorities. The same note foresees that situations may occur where IMF staff would even need to prioritise gender issues (before other economic considerations). The note therefore advices IMF staff to "consider an alternative policy mix to prevent such negative externalities or - if the former is not feasible - suggest some mitigating measures", but also to consider "potential trade-offs between government conditionality to improve targeting, such as means-testing, and their gender impact". This could potentially be read as an outright entitlement to elevate a gender perspective to the level of (other) macro-economic considerations. ${ }^{126}$

The vulnerable position of youth stands out as somewhat less explicit in terms of demonstrating macro-criticality. Nevertheless, youth, and the consequences of youth unemployment on economic growth in particular, are recognised policy concerns. Apart from the social costs, high youth unemployment is noted to be detrimental to medium-term growth prospects and the sustainability of social spending. Long-term consequences for economic growth follow from the loss or degradation of human capital. ${ }^{127}$

\section{$9 \quad$ Protection of Vulnerable Groups and the Question of Mandate}

The requirement of macro-criticality that qualifies the IMF social protection engagement is commonly accused of leading to a too insensitive approach to social effects, for gearing IMF attention to fiscal concerns and for allowing social spending cuts. ${ }^{128}$ While these critiques may all be true, conceptually the macro-criticality threshold should be seen as an inherent part of the IMF 'mandate.'The functional nature of intergovernmental organisations is present

125 Guidance Note for Surveillance, supra note 54, para. 81; Bretton Woods Project, The IMF and Gender Equality: Operationalising Change (February 2019), <https://www.bretton woodsproject.org/2019/o2/the-imf-and-gender-equality-operationalising-change/>, visited 9 January $2020, \mathrm{p} .3$.

126 How to Operationalize, supra note 123.

127 Social Spending Strategy, supra note 5o, p. 9; A. Banerji et al., Youth Unemployment in Advanced Economies in Europe: Searching for Solutions, International Monetary Fund Staff Discussion Note (December 2014) p. 7; N. Shafik, 'Stolen Dreams', 49:1 Finance \& Development (2012) pp. 18-19.

128 Recently e.g., L. Merling, 'IMF framework on social spending out of step with international standards', <https://www.brettonwoodsproject.org/2019/o7/imf-framework-on -social-spending-out-of-step-with-international-standards/>, visited 30 July 2019. 
in various ways in their constituent instruments. First, it is present in the presumption that intergovernmental organisations are limited in all their tasks to the pursuit of their individual aims and purposes, as defined in the constituent instrument. This means that organisations can only exercise powers that are explicitly conferred upon the organisation for pursuing those aims, or such non-express powers that can be found to be necessary (and can therefore be implied). ${ }^{129}$

Another expression of the functional nature of organisations is the inclusion of explicit safeguards that protect what members perceive as their sovereign sphere, from interference by the organisation. ${ }^{130}$ This principle is embodied in Article 4(3) of the Articles of Agreement of the IMF, which states that the IMF "shall respect the domestic social and political policies of members". ${ }^{131}$ Also the threshold of macro-criticality that guides Fund policy-making constitutes a defining feature of the conferral of powers to the Fund, defining IMF legitimate sphere of action. The purpose of both principles is to ensure that the exercise of powers and performance of functions by the IMF only pursues the purposes of the organisation, as defined in the Articles of Agreement.

This functional nature characterises the social protection engagement of all organisations. The World Bank has noted that about half of the agencies that have programmes addressing labour market issues consider social insurance and safety net operations as part of social protection, whereas several agencies only consider parts of the labour agenda as social protection, according to the mandate of the organisation. ${ }^{132}$ The limited mandate is also referred to by the IMF as an obstacle to engage with issues of rights, and for establishing conditions that are related to the human rights situation in a lending state. ${ }^{133}$

As the demonstration of macro-criticality constitutes a defining feature of IMF competence, an extension of the Fund's social engagement requires a broadened conception of macroeconomic variables affecting the 'stability of

129 Legality of the Use by a State of Nuclear Weapons in Armed Conflict, 8 July 1996, ICJ, Advisory Opinion, paras. 21-25.

130 Prominent examples being UNCharter Article 2(7); and The Treaty on the European Union, Article 5.

131 Also see Decision on Bilateral and Multilateral Surveillance, supra note 54, para. 15.

132 The World Bank, The World Bank 2012-2022 Social Protection and Labor Strategy (2012), p. 96 .

133 de Chazournes, supra note 37, pp. 213-214; R.B. Leckow, 'Conditionality in the International Monetary Fund', 3 Current Developments in Monetary and Financial Law (2005) pp. 53-64. The IMF is also reluctant to second-guess state social protection needs and its definition and prioritisation of vulnerable groups due to lack of expertise. 
the monetary system' or the 'balanced growth of trade.'134 This is an expression of the enabling aspect of the functional nature of international organisations. Redefining macro-criticality is a slightly different question than invoking the implied powers of the IMF. To put it in other terms, 'competence creep' can occur in various ways. The sphere of action of an organisation can expand through redefining the aims and objectives of an organisation or the powers conferred upon it, but also through reinterpreting thresholds that limit the acts of organisations. The sphere of United Nations Security Council decisionmaking, for example, has expanded through the evolving interpretation of the threshold that Article 39 of the UN Charter establishes (the requirement of a "threat to the peace"). ${ }^{135}$ For the Fund a reinterpretation of macro-criticality in a similar way leads to a broadening of the 'mandate' of the organisation. A good example of the expanding mandate is gender equality, the macro-economic dimension of which has gradually become accepted within the Fund. ${ }^{136} \mathrm{~A}$ broadening conception of macro-criticality engages the IMF in discourses rooted in the human rights sphere.

At the same time it should be noted that even in the case of gender, it is not the sociological construction of gender equality as such that is the main concern for the Fund. Similarly, in a situation where acceptable child work can be seen as economically beneficial for a country, while the worst forms of child labour fail to display macro-critical effects on sustainability and growth, child labour becomes a paradigm example of how the mandate of the IMF and the absence of an established link to macroeconomic performance qualifies its approach to vulnerable groups. ${ }^{137}$ It should also be noted that although it is the international organisation which interprets the scope of its mandate in the

134 Discussed already in 1991, by G.K. Helleiner, G.A. Cornia and R. Jolly, 'IMF Adjustment Policies and Approaches and the Needs of Children', 19:12 World Development (1991) pp. $1823-1834$.

135 ICTY, Prosecutor v. Duško Tadić a/k/a "Dule", Decision on the Defence Motion for Interlocutory Appeal on Jurisdiction, 2.10.1995.

136 K. Kochhar, S. Jain-Chandra and M. Newiak, Women, Work, and Economic Growth: Leveling the Playing Field (International Monetary Fund, Washington, DC, 2017).

137 Child labour in this sense refers to work that is hazardous, interferes with education or is harmful to physical and mental development. Convention on the Rights of the Child, Article 32. See e.g., S. Dillon, 'Child Labour and the Global Economy: Abolition or Acceptance?', 84:2 Nordic Journal of International Law (2015) pp. 297-322; and M.N. Browne, et al., 'Universal Moral Principles and the Law: The Failure of One-Size-Fits-All Child Labor Laws', 27:1 Houston Journal of International Law (2004) pp. 1-45. 
first place, ${ }^{138}$ any reinterpretation of that scope must enjoy a degree of acceptance among the membership. ${ }^{139}$ Otherwise member states will invoke their right to expect that the IMF does not interfere with what they perceive as domestic concerns. ${ }^{140}$

\section{Vulnerability in IMF Institutional Law}

The normative weight that the protection of vulnerable groups assumes, follows from the context and status of instruments in which it is invoked. As a general rule the legal nature of acts of organisations is determined by the constituent instrument. ${ }^{141}$ The IMF Articles of Agreement set the framework for the internal law of the organisation. In addition to the Articles, there are three main sources of IMF laws: the Fund's by-laws and resolutions adopted by the Board of Governors, regulations and decisions adopted by the Executive Board and general administrative orders and staff guidance notes issued by the Managing Director. ${ }^{142}$ The Guidance Note for Surveillance and the Conditionality Guidelines both constitute staff guidance notes, and are as such part of the body of IMF laws. The Strategy on Social Spending is a Policy Paper, which has been endorsed by the Executive Board. As an indication of its intended guiding effect, the Board noted that "staff is expected to strengthen its focus on social spending in line with the agreed strategy". ${ }^{143}$ While all these documents are geared towards IMF staff, they become part of the normative order governing

138 The principle was established already by the Permanent Court of International Justice: "as a general rule, any body possessing jurisdictional power has the right in the first place itself to determine the extent of its jurisdiction", Interpretation of the Greco-Turkish Agreement of December 1st, 1926 (Final Protocol, Article IV) (Advisory Opinion, 28 August 1928), PCIJ Publications 1928, Series B, no. 16, p. 20.

139 R.C. Hockett, "From Macro to Micro to "Mission-Creep": Defending the IMF's Emerging Concern with the Infrastructural Prerequisites to Global Financial Stability', 41:1 Columbia Journal of Transnational Law (2002) pp. 153-193.

140 Which is not uncommon in the IMF. By way of examples see Tan and Selowsky, supra note 86, on Latvia and Romania. Also Wagner and Zhou, supra note 8, on Cyprus. The IMF and Social Protection (2018), supra note 10, p. 26 makes the same conclusion out of interviews conducted.

141 The constituent instrument may, of course, also be silent on the type of act (or its nature) to be adopted, and practice may have generated acts not envisaged by the drafters. J. Klabbers, An Introduction to International Institutional Law (Cambridge University Press, Cambridge, 2009) p. 178.

142 Y. Liu, 'The Rule of Law in the International Monetary Fund: Past, Present and Future', AIIB Yearbook of International Law (2018) pp. 39-49.

143 Social Spending Strategy, supra note $5^{0 .}$ 
the activities of the organisation. As part of the law of the IMF they come with a strong expectation of compliance. ${ }^{144}$

In performing its main functions towards the member states, while the Fund has the responsibility to conduct surveillance of all members' policies that potentially affect domestic economic and financial stability, it also creates a formal obligation of member countries to collaborate with the organisation as well as with other members. Overall, the Fund's surveillance tools are 'soft' (surveillance sometimes described as a process of 'educating' national officials). However, throughout its existence both IMF members as well as its staff have been noted to be observably committed to and constrained by the Articles of Agreement and the by-laws; IMF surveillance even being characterised as a form of regulatory supervision. This means that despite a lack of formally binding character, also IMF social protection advice can gain considerable political and regulatory impact. ${ }^{145}$

As to lending conditionality as the most forceful tool at the IMF's disposal, when a country borrows from the IMF, its commitments (including conditionality) are described in the member country's letter of intent. The decision to lend is approved by the IMF Executive Board in a Memorandum of Understanding (MoU). Conditionality, as set forth in the MoU has an impact on the political autonomy of the lending state, as loan disbursement is made conditional upon meeting the programme goals. ${ }^{146}$ Regulatory impact can also derive from implementation by other bodies (such as the EU Council). ${ }^{147}$

As a question of the law of treaties, a MoU can indicate both a treaty and a legally non-binding act. In order to find out the true nature of a MoU, interest

144 This is a general principle of international institutional law, see e.g., P. Sands and P. Klein, Bowett's Law of International Institutions (Sweet \& Maxwell, London, 2001) p. 455; and C.F. Amerasinghe, Principles of the Institutional Law of International Organizations (Cambridge University Press, Cambridge, 2005) pp. 179 and 188.

145 D. Lombardi and N. Woods, 'The Politics of Influence: An Analysis of IMF Surveillance', 15 Review of International Political Economy (2008). Although the Articles of Agreement do entail a sanctioning mechanism, it has never been used. A. Feibelman, 'Law in the Global Order: The IMF and Financial Regulation', 49:3 International Law and Politics (2017) pp. $687-745$.

146 C. Joerges, 'Three Transformations of Europe and the Search for a Way Out of its Crisis' in C. Joerges and C. Glinski (eds.), The European Crisis and the Transformation of Transnational Governance: Authoritarian Managerialism Versus Democratic Governance (Hart Publishing, Portland, 2014), 24-46.

147 A. Baraggia, 'Conditionality through the lens of the cJEu: a "blurry" view', Verfassungsblog (30 June 2016), <https://verfassungsblog.de/conditionality-through-the-lens-of-the-cjeu -a-blurry-view/>, visited 6 September 2018. 
must be turned to the intentions of the parties and the content of the MoU. ${ }^{148}$ The language used in IMF memoranda suggests that a contractual nature is not intended. ${ }^{149}$ As such, the arrangement is not an agreement between the Fund and the member, but better characterised as a unilateral decision (or commitment) by the Fund's Executive Board. Yet, although the arrangement is not formally an agreement, it is a legal instrument in the sense of providing the member with certain rights (above all, to make purchases subject to the conditions of the arrangement). ${ }^{150}$

In the review of country performance, focus is on key programme targets (Quantitative Performance Criteria and Indicative Targets). In this respect, there is a built-in structural issue that works to the detriment for example of social spending floors as a means for taking vulnerable groups into consideration. This derives from the non-binding nature of 'social and other priority spending' (commonly defined as Indicative Targets), compared to key macroeconomic targets (defined as Quantitative Performance Criteria). Although the social spending targets appear in the conditionality tables of IMF loan reports, their non-binding character has meant that they lack impact on loan disbursements if not attained. Across all lending facilities, only five per cent of social spending floors have been set as Performance Criteria (since 2012). ${ }^{151}$ Nevertheless, in the largest loan in IMF history (Argentina 2018), a social assistance floor which targeted most vulnerable households was defined as a Performance Criteria, elevating the spending floor to a full loan condition. ${ }^{152}$ As it is up to country teams to set programme targets as either Performance Criteria or Indicative Targets, the broadening conception of macro-criticality enables that spending floors are set as binding targets. Although progress in achieving programme objectives is assessed holistically, such an elevation of the protection of vulnerable groups into a precondition for further disbursements forces

148 A. Aust, Modern Treaty Law and Practice (Cambridge University Press, Cambridge, 2013), pp. 21-28.

149 M. Meng-Papantoni, 'Legal Aspects of the Memoranda of Understanding in the Greek Debt Crisis', 18 Zeitschrift für Europarechtliche Studien (2015) pp. 3-26 p. 19.

150 R. Leckow, 'The Stand-By Arrangement: Its Legal Nature and Principal Features', in International Monetary Fund, 2 Current Developments in Monetary and Financial Law (2003) pp. 33-50, pp. 37-39. Also the Greek Council of State has ruled (Decision 668/2012) that the $\mathrm{MoU}$ is not an international agreement.

151 Social Spending Strategy, supra note 50, p. 34.

$15^{2}$ International Monetary Fund Country Report No. 18/297, Argentina: First Review under the Stand-By Arrangement; Inflation Consultation; Financing Assurances Review; and Request for Rephasing, Augmentation, Waivers of Nonobservance and Applicability of Performance Criteria, and Modification of Performance Criteria-Press Release; Staff Report; and Staff Supplement (26 October 2018), pp. 77-78. 
both the lending state and the IMF to address the question, already because of the fact that the state has an obligation to apply for a waiver from the IMF Executive Board in case it fails to reach a Performance Criteria.

Another consequence of embedding the vulnerability concept in the institutional law of the IMF derives from the expectation that states are to define their social protection needs in Poverty Reduction Strategy Papers (PRSPS). PRSPS are national planning frameworks for low-income countries. Both the World Bank and the IMF require countries to produce a PRSP as a condition for debt relief and concessional lending. ${ }^{153} \mathrm{~A}$ basic yardstick in assessing the content of PRSPS is whether they contain information and analysis on specific poverty groups and social categories that may be subject to exclusion. This means that while these strategies focus on poverty reduction, they are to identify sources and levels of vulnerability. ${ }^{154}$ If there earlier has been a critique towards the quality and comprehensiveness of such analyses, the IMF framework itself now provides an incentive for assessing vulnerabilities. In other words, the stronger the protection of vulnerable groups becomes embedded as an element of IMF lending programme design, the higher the expectation will be for those concerns to be addressed also in PRSPS. As the mandatory nature of the PRSP process renders the content of PRSPS into something of binding requirements, ${ }^{155}$ and as the PRSPS are to inform domestic authorities and country teams in defining programme targets, their role as a source for both defining vulnerability and identifying vulnerable groups could therefore be enhanced.

153 International Monetary Fund Factsheet, IMF Support for Low-Income Countries (8 March 2018); C. Tan, 'The New Biopower: Poverty Reduction Strategy Papers and the Obfuscation of International Collective Responsibility', 32:6 Third World Quarterly (2011) pp. 1039-1056, p. 1039.

154 G Nankani, J. Page, and L. Judge, 'Human Rights and Poverty Reduction Strategies: Moving Towards Convergence?', in P. Alston and M. Robinson (eds.), Human Rights and Development: Towards Mutual Reinforcement (Oxford University Press, Oxford, 2005), 476-497; A. McBeth, International Economic Actors and Human Rights (Routledge 2009) pp. 191193. None of this is to deny the critique made towards such strategies, taking hold of a lack of genuine commitment to the notion of country ownership, the challenge posed to parliamentary democracy, the failure to generate broad-based participation of civil society, the nature and quality of consultations and an incapacity to embrace contradictory policies demanded by the public. G. de Burca, 'Developing Democracy Beyond the State', 46:2 Columbia Journal of Transnational Law (2008) pp. 221-278.

Tan (2011), supra note 153, p. 1043. 


\section{Appreciating IMF Endorsement?}

While it would be an overstatement to say that the protection of vulnerable groups is mainstreamed in IMF policy-making, the door is certainly open for incorporating such concerns across the performance of IMF tasks. The consequent question is whether IMF endorsement of the vulnerability concept can contribute to the advancement within states of rights of vulnerable groups. ${ }^{156}$ It is clear from the outset that there is a difference between the concept of vulnerability as emerging in human rights law, and the use of the concept in IMF policy-making. As a question of "trade and human rights", the compatibility of conceptions of rights-related concepts and principles has attracted much attention. In this discourse, a human rights-based approach highlights the differing normative foundations of the two regimes. ${ }^{157}$ Human rights are recognised for all based on the inherent human dignity of all persons, while traderelated rights are granted to individuals for instrumental reasons. Whereas the trade agenda ultimately has a utilitarian or consequentialist focus, the argument goes, human rights law is deontological, protecting each and every individual regardless of utility. 158

This fault-line is present in different ways in IMF social protection engagement. It runs between a "social safety net" approach and a human rights or "social citizenship" approach to social protection. ${ }^{159}$ Also the discussion on the use and design of protection floors echo this division, with the IMF preferring targeted protection schemes in order to avoid costly inclusion errors, whereas a human rights based approach departs from universality. ${ }^{160}$ This difference is clearly visible also in the way in which vulnerable groups can become a concern for the IMF. As the IMF does not operate with a holistic understanding of vulnerable groups, it will always therefore also apply a narrower assessment

${ }_{15} 6$ A question posed also e.g., by B. Kingsbury, 'Introduction: Global Administrative Law in the Institutional Practice of Global Regulatory Governance', in H. Cissé, D. Bradlow, and B. Kingsbury (eds.), 3 The World Bank Legal Review (2011): International Financial Institutions and Global Legal Governance (World Bank Group, 2012), 3-33, p. 11.

157 See e.g., M. Hertig Randall, 'Human Rights Within a Multilayered Constitution: The Example of Freedom of Expression and the WTO', 16 Max Planck Yearbook of United Nations Law (2012) pp. 183-280.

158 S. Joseph, Blame it on the WTO?: A Human Rights Critique (Oxford University Press, Oxford, 2011), pp. 36-37.

159 See Report of the Special Rapporteur on extreme poverty and human rights, Extreme poverty and human rights, UN Doc. A/69/297 (11 August 2014), para. 21

16o Although the reality of this distinction can be questioned. See V. Engström, 'Unpacking the Debate on Social Protection Floors', 9:3 Göttingen Journal of International Law (2019) pp. $57^{-}-599$. 
of competing values. ${ }^{161}$ Even if the conception of macro-criticality may be expanding, all conceivable macro-critical issues do not become subject to social spending. Instead, priorities are struck among macro-critical issues. Priorities may also change over time. ${ }^{162}$ Whereas in respect of Greece, for example, lowincome retirees was a group recognised as particularly vulnerable in early IMF programmes, ${ }^{163}$ the IMF Country Report on Greece from 2016 proposed that spending should be rebalanced from pensions to protection of other vulnerable groups and essential public services and investment. ${ }^{164}$

Also in respect of particular groups, the IMF adopts a narrow approach to vulnerability. ${ }^{165}$ In the case of gender, for example, the IMF typically focuses on female labour force participation rates and the gender pay gap, hereby highlighting only two elements of the multifaceted gender equality problem. The IMF itself recognises that measures such as budget cuts on subsidies, social programmes and the public-sector wage bill are examples of policies that could exacerbate gender inequality. Yet, these are frequently recommended as ways of reducing government spending. ${ }^{166}$

161 M.E. Salomon and C. Arnott, 'Better Development Decision-making: Applying International Human Rights Law to Neoclassical Economics', 32:1 Nordic Journal of Human Rights (2014) pp. 44-74; Center for Economic and Social Rights, Assessing Austerity: Monitoring the human rights impacts of fiscal consolidation, February 2018, p. 11.

162 Social Spending Strategy, supra note 50, p. 27.

163 International Monetary Fund Country Report No. 10/110, Greece: Staff Report on Request for Stand-By Arrangement (10 May 2010), pp. 11-12. Also see e.g., M. Soto, V. Thakoor and M. Petri, Pension Reforms in Mauritius: Fair and Fast - Balancing Social Protection and Fiscal Sustainability, International Monetary Fund Working Paper WP/15/126 (19 June 2015).

164 The reason for this rebalancing was that poverty in old age had been declining, while poverty for the working age population and the unemployed had been rising. A rationalisation of pension spending was called for through lowering benefits for those with higher pensions and shorter working histories to the benefit for retirees with lower pensions and longer contribution periods. This was also seen as a way to free means for health service investment, and to bring about a fairer intergenerational burden-sharing of reform costs. International Monetary Fund Country Report No. 17/40, Greece, 2016 Article IV Consultation; Press Release; Staff Report; and Statement by the Executive Director for Greece (7 February 2017), pp. 17-24.

165 M. Broberga and H.-O. Sano, 'Strengths and weaknesses in a human rights-based approach to international development - an analysis of a rights-based approach to development assistance based on practical experiences', 22:5 The International Journal of Human Rights (2017) pp. 664-68o.

166 International Monetary Fund Guidance Note, Operationalizing Gender Issues in Country Work, (2018), para. 26. Also see UN Independent Expert on Foreign Debt and other related international financial obligations of States on the full enjoyment of all human rights, particularly economic, social and cultural rights, Impacts of economic reforms and austerity measures on women's human rights, UN Doc. A/73/179 (18 July 2018). Also Bretton Woods Project, The IMF and Gender Equality: Operationalising Change (February 2019), 
On the other hand, the expansion of the values that can be taken into account in IMF policy-making could be seen against the background of other transnational communities in which rights become part of a wider common enterprise (such as the European Union or the WTO). In such communities, characteristically, a more limited conception of rights is invoked. ${ }^{167}$ The rights invoked are also interpreted in light of that common enterprise. While human rights law is a strong candidate for acting as an overarching narrative when international legal regimes interact, such a position of predominance is still in the making. This seems particularly apparent concerning the concept of vulnerability, which still seeks conceptualisation also in human rights law. In the absence of an overarching narrative, the IMF endorsement of the protection of vulnerable groups becomes a step in the process of knowledge production that defines the very concept itself. ${ }^{168}$ Regime interaction hereby becomes a dialogue on the meaning and function of the concept of vulnerability in international law. ${ }^{169}$

IMF social protection engagement does expand on the set of actors raising concerns over vulnerable groups with domestic policy-makers. It may also broaden the scope of actors who are confronted with the question. While the World Bank and other development partners work with relevant ministries on social protection issues, the IMF is commonly directly engaged with the finance ministry. ${ }^{170}$ It should also be noted that as protection of vulnerable groups becomes part of the institutional law of the IMF, it also becomes a parameter by which to assess the acts of the Fund itself (irrespective of the possibility of asserting human rights responsibilities on international financial institutions). Yet another point to acknowledge is the politically and normatively powerful position of the IMF, especially towards lending states. This

$<$ https://www.brettonwoodsproject.org/2019/o2/the-imf-and-gender-equalityoperationalising-change/>, visited 11 February 2020.

167 N. Walker, 'Universalism and Particularism in Human Rights: Trade-Off or Productive Tension?', 10 University of Edinburgh, School of Law, Research Paper Series (2012).

168 M.N. Barnett and M. Finnemore, 'The Politics, Power and Pathologies of International Organizations', 53:4 International Organization (1999) pp. 699-732; J.L. Dunoff, 'A New Approach to Regime Interaction', in M.A. Young, Regime Interaction in International Law: Facing Fragmentation (Cambridge University Press, Cambridge, 2012) pp. 136-174, pp. 154-155 and 167 .

169 Ibid., p. 169. In a similar way poverty reduction strategies have been noted to have the capacity to develop and crystallize rights. E.g., R. Perry, 'Preserving Discursive Spaces to Promote Human Rights: Poverty Reduction Strategy, Human Rights and Development Discourse', 7:1 McGill Journal of Sustainable Development Law (2011) pp. 61-87.

170 IMF staff interviewees with experience with working on low-income countries experience that there has been a role for the IMF to speak in favour of social safety nets in dialogues with finance ministries. Klugman et al., supra note 44, p. 5 . 
means that as the protection of vulnerable groups is firmly established as a guiding principle in IMF decision-making, the IMF is seated in a position to monitor and implement that protection. ${ }^{111}$ This, of course, is a double-edged sword. If the IMF fails to be systematic in raising vulnerability concerns, the endorsement will only undermine the reputation of the IMF social protection engagement further.

The fierce discourse over IMF policy-making underlines the social dimension of its decisions. IMF policies have been associated with increased disease, suicide and maternal mortality, for not meeting its own indicative targets and for preventing countries from improving social protection in the long run. ${ }^{172}$ In response, the IMF has in recent years made a strong claim to take into account the social impact of its policy prescriptions. With this, the IMF is in good company, as social protection policies are adopted across regimes at increasing pace. The aim of the present article has been to identify the function of the vulnerability concept as invoked in the policy-making of the IMF.

As most of the 189 IMF member states are also parties to at least some human rights conventions that embody the idea of enhanced protection of particular groups, it is perhaps not that surprising to find that there is a degree of resemblance between vulnerable groups identified in IMF policy-making and in human rights instruments. Nevertheless, the fact that concern for vulnerable groups has entered IMF policy-making is remarkable in its own right. The expanding conception of macro-criticality and the emphasis on mitigating the impact of adjustment on vulnerable groups establishes protection of vulnerable groups as a criterion by which to also assess the activities of the IMF itself.

This article has not been concerned with the question of effectiveness of IMF vulnerability endorsement - a task better left to socio-legal studies. Some studies indicate that the IMF still has a long way to go in this respect. ${ }^{173}$ At the

\footnotetext{
171 On financial institutions in general, see e.g., C. Brummer, Soft Law and the Global Financial System: Rule Making in the $27^{\text {st }}$ Century (Cambridge University Press, New York, 2012).

172 See e.g., J. Wojnilower, External Perspectives on the IMF and Social Protection, Independent Evaluation Office Background Document No. BD/17-01/o2 (5 July 2017), summing up the critique.

173 See e.g., T.H. Stubbs and A.E. Kentikelenis, 'Conditionality and sovereign debt: An overview of human rights implications', in I. Bantekas and C. Lumina (eds.), Sovereign Debt and Human Rights (Oxford University Press, Oxford, 2019) 359-380; Mariotti et al., supra note 16 .
} 
same time the human rights based approach to vulnerability is not immune to criticism either, leaving the concept in need of further analytic attention. ${ }^{174}$ The IMF's gradual move beyond the traditional 'fiscal centric' approach to recognise the macro-criticality of a range of social concerns does not mean that it has overhauled the macroeconomic policy framework. ${ }^{175}$ After all, upholding this framework is its raison d'être. It would also be a misinterpretation to regard the development as an instance of mainstreaming of human rights law. Many open questions also remain, such as the expertise of IMF staff to assess complex social protection issues, and the formulation of policy alternatives. The staff guidance to be adopted in 2020 will be an important addition in this respect. Yet, for all the shortcomings, IMF endorsement of the protection of vulnerable groups is a step in broadening the value-base of the Fund. For good or bad, the political authority of the IMF also positions the organisation as a source for identification of vulnerable groups, with potential to implement that protection.

174 On the failure to address structural concerns, see Fineman, supra note 19. On the problem of human rights mainstreaming, see e.g., D. Clément, 'Human rights or social justice? The problem of rights inflation', 22:2 The International Journal of Human Rights (2018) pp. 155-169, p. 156; Broberg and Sano, supra note 165; and Dillon, supra note 137, p. 322.

175 Critical voices are however emerging also within the IMF. See J.D. Ostry, P. Loungani and D. Furceri, 'Neoliberalism: Oversold?', 53:2 Finance \& Development (2016) pp. 38-41. 